\title{
The Theological Implications of the Council's Liturgical Constitution: Changes in the Concept of the Sacrament of Anointing of the Sick*
}

The Council of Trent, by listing the sacraments instituted by Christ, gave fifth place to the last rites, extrema unctio (D 844). This is the name under which the sacrament has been known to the faithful and discussed by theology until today. The liturgical Constitution of the Second Vatican Council deals with it in Chapter 3, points 73-75, and makes the following provision: 73. The "last rites," which can also - and better - be called the "anointing of the sick," is not a sacrament intended for those who are in ultimate danger of losing their lives, in extremo vitae periculo. Therefore, the right time to receive this sacrament certainly occurs, certe habetur, when the faithful begins to be, incipit esse, in danger of death from illness or old age. 74. In addition to the rite of the anointing of the sick and the viaticum, a continuous rite should be performed in which the Anointing is given to the sick after confession and before the acceptance of the Vatican. 75. The number of Anointings must be adapted to the circumstances, and the prayers of the Anointing of the Sick rite must be adapted to suit the different categories of the sick who receive the Sacrament ${ }^{1}$.

* STV 3(1965)1.

1 73. “Extrema Unctio', quae etiam et melius 'Unctio Infirmorum' vocari potest, non est Sacramentum eorum tantum qui in extremo vi tae discrimine versantur. Proinde tempus opportunum eam recipiendi iam certe habetur cum fidelis incipit esse in periculo mortis propter infirmitatem vel senium. 74. Praeter ritus seiunctos Unctionis infirmorum et Viatici, conficiatur Ordo continuus secundum quem Unctio aegroto conferatur post confessionem et ante receptionem Viatici. 75. Unctionum numerus pro oportunitate accommodetur, et orationes ad ritum Unctionis pertinentes ita recognoscantur, ut respondeant variis condicionibus infirmorum, qui Sacramentum suscipiunt." 
In points 74 and 75 we find only practical provisions, while the first sentence of point 73 gives the doctrinal principle justifying practical provisions that start with the second sentence of point 73 . The doctrinal principle and the practical provisions of paragraph 73 complement and clarify each other: the doctrinal principle defines the name and proper subject of the sacrament; the practical provision speaks of the time appropriate for the administration of the sacrament.

The theological doctrine on the sacraments shows that the proper purpose is essential to the structure of each sacrament: the nature of sacramental grace is subordinate to it, and this determines the nature of the sacramental sign and even the minister. Every change made in the definition of the purpose of the sacrament should have far-reaching consequences. If, therefore, the liturgical conciliar constitution, directly or indirectly, were to specify the purpose of the sacrament of the Anointing of the Sick, other than the theological theories accepted so far, its decision would have not only a fundamental, but perhaps even a crucial meaning for the theology of the sacrament of the Anointing of the Sick. The purpose of this treatise is precisely to examine to what extent and in relation to which theological theories the liturgical constitution makes changes to the concept of the fifth sacrament. In order to fulfil such a defined idea, we need to determine in advance the direct content of the Council Decree, and then we should consider what conclusions are necessary or deductive from it.

It must be emphasised that it is not the purpose of this treatise to present all theological teachings about the fifth sacrament. After all, it is not a systematic, textbook approach, whose knowledge it presupposes, but only speaks about what - following the Council Decree - should be changed from now on in the textbook dogmatic lecture.

What, then, is the proper and direct content of paragraph 73 of the liturgical constitution, which is most important for the theological doctrine of the sacrament of the anointing of the sick? It begins with the introduction of the new name "anointing of the sick," but does not reject the name "last rites," which has been in common use since the $18^{\text {th }}$ century and introduced by the Council of Trent in the dogmatic decree on the number of sacraments instituted by Christ. Neither does it reject, nor consider the previous name of "last rites" as wrong, for the name "the anointing of the sick" is only better than that name, and it says that the last rites can also, etiam et melius, be called the anointing of the sick. Leaving the current name as fundamentally acceptable is not only historically explained by the fact that it was used by the Council of Trent, which the Second Vatican Council does not want to pillory, but also has its theoretical justification in that the name "last rites" is not inextricably linked with the 
medieval concept of this sacrament and therefore is not in contradiction with the new approach, initiated by point 73 of the liturgical constitution. Namely, in the Middle Ages this sacrament was originally named, in fact, the last rites because at the time at which it was given, and not because of the kind of sacramental grace attached to it; that is, because it was given at the end, after other sacraments had been received, so it was the last sacrament temporarily received in life. This custom, as well as the name "last rites," existed already in the $10^{\text {th }}$ and $11^{\text {th }}$ centuries, that is, before the representatives of the great scholastic community built it up with their theories: if the name existed before the theories were born, it can in principle remain after their rejection.

In turn, since in the name "last rites" the adjective "last" has actually a temporal meaning, the following conclusion is necessary: the term "last rites" is not evil, i.e. its meaning does not contradict the revealed doctrine of the proper purpose and effects of the sacrament of the sick. If it is not bad, the council had no basis for rejecting it.

The name "Anointing of the Sick" is, however, better directly because it does not tighten the timing of its provision to the last moments of life, i.e. it does not make it either in practice or in theory a dying sacrament; it is indirectly better because it frees the sacrament from all historical and theological ties with which the Council later breaks off. From the Council's comparative evaluation of the two names of the sacrament, a clear practical idea emerges: the Council wants the name "Anointing of the Sick" to replace "Last Rites" in future theological textbooks and catechism. In order to encourage this with its example, the Council uses the name 'Anointing of the Sick' in the remainder of the decree.

The most important doctrinal provision of paragraph 3 properly and directly concerns the subject receiving the sacrament and is expressed in a negative sentence: the sacramental anointing is intended not only for those who are in imminent danger of death. This decision rejects the superstitions of the faithful and the theological theories that have made the sacrament of the sick the sacrament of the dying in theory and practice. Its direct content undermines even the deepest theories of sacramental theology that the great scholastics of the Middle Ages have managed to develop. The sentence of St. John of God is irreconcilable with St. Thomas Aquinas, who claimed that the sacrament of the anointing of the sick is intended for those who leave this world, that is, for the dying, pro statu exeuntium ${ }^{2}$; it is also contrary to the decree of St. Bonaventure 
that sacramental anointing should be given to the sick only when they are dying or when they are certain to die; but if it were certain that they would recover from illness, they could not be sacramentally anointed ${ }^{3}$. It is all the more contradicted by the extreme theory of Johannes Duns Scotus, according to which the sacramental anointing of the sick has its full effect only when it is given when the sick person, because of collapsing, can no longer $\sin ^{4}$. Since these views of the great scholastic doctors are the conclusions of their definition of the proper purpose and grace of the sacrament of the Anointing of the Sick, this doctrinal provision of the liturgical constitution must indirectly weigh on the whole of their theory: part two will clarify the extent to which this is the case.

The second sentence of paragraph 3 of the Constitution begins with the resultant conjunctiva proinde, "therefore," which indicates that the thought expressed in it is the consequence and conclusion of the principle expressed in the preceding sentence. In fact, it is only partly a conclusion; partly it supplements the principle previously expressed in a negative form: having said in the preceding sentence how the subject of the sacrament of the Anointing of the Sick cannot be tightened, the Council now indicates who its subject actually is. The definition of the subject is inextricably linked with the timing of the sacrament. The Council states, first of all, that the subject of the sacrament is every faithful person who is in danger of death because of illness or old age; and secondly, that it is the subject of the sacrament from the first moment when, for these two reasons, incipit esse, he is in danger of death. From this moment on, it is also the right time to administer the sacrament. It is clear that the Council only means genuine and serious danger of death. Finally, in the same sentence, the Council indicates the degree of certainty of its definition of the subject and the time of reception of the sacramental anointing of the sick: it considers both to be certain, certe habetur.

The definition of the subject of the sacramental anointing of the sick adopted by the Council highlights the magnitude of the opposition between the position of the Council and the theses of the doctors of the great scholastic school when they preached: "only the last moments of life are the time to receive this sacrament," the Council decides: "the time for receiving the sacramental anointing begins with the first moment when there is a serious danger of losing one's life because of illness or old age."

$3 \quad$ IV dist 23 art 1 quo 1 ad 1.

4 Opus Oxon. IV dist 23 No. 3 
Certainty is attributed by the liturgical Constitution explicitly only to the definition of the subject and the time of receiving the sacrament of the sick, certe hebetur. There is no doubt, however, that not only this, but all the doctrinal provisions of paragraph 3 of the Constitution are theologically certain and would be certain even if the Council had not indicated this certainty at all, even in a single word. They are certain because they meet all the conditions for certainty. Although they do not have infallible certainty in their dogmas, since the entire liturgical Constitution lacks even the slightest indication that the Council intends to proclaim a new dogma in it. What is more, the Council set itself such a pastoral goal that it ruled out in advance the possibility of proclaiming new dogmas. The doctrinal provisions of paragraph 3 of the Constitution, however, have true, albeit erroneous, theological certainty. In the light of the theological methodology ${ }^{5}$, such certainty is given to all the decisions of Councils and Popes which, although not taken as definitive and infallible, nevertheless explain the doctrine revealed by the choice between two conflicting opinions: in fact, then the Church already resolves the doctrinal dispute and thus takes the first step on the road to a final or infallible explanation of the doctrine of the revealed. The history of the text of the liturgical Constitution, on the other hand, speaks very clearly to what extent the provisions of paragraph 3 were an act of choice between two opposing theses. The original wording of the scheme was an attempt to go beyond the general formulation of the Code of Canon Law by adopting the scholastic concept of the Fifth Sacrament: "this anointing should be given only to the sick, and not to all, as the tradition of the Church teaches us, but only to those who are so seriously ill that they may be considered to be at the end of their lives. If the Council had agreed to such a definition of the subject of this sacrament, it would have made it the sacrament of the dying and discouraged many believers from receiving it. The Council wanted as many seriously ill Christians as possible to benefit from the grace of the sacrament and therefore decided to disperse prejudices surrounding the sacrament, including the fact that it is the sacrament of the dying. This pastoral consideration led the Council to completely reject the original wording of the scheme and made the precision brought by the provisions of paragraph 3 to the general norms of canon law contradict the scholastic understanding of the subject of this sacrament.

The doctrinal provisions of paragraph 3 of the Constitution are a clear step forward in explaining the doctrine of the revealed doctrine, even compared 
to canon 940 of the Code of Canon Law: "The last anointing may be given only to the faithful who, having used reason, are in danger of losing life because of illness or old age." Although the aforementioned canon considers every serious threat to life by sickness or old age to be a necessary and sufficient condition for the giving of sacramental anointing, one could still insist on a scholastic interpretation: in every serious danger to life, but not at its beginning, but when the danger to life approaches its fatal end. All theologians who supported the theories of their scholastic masters until the last few days without the slightest change had to give a similar interpretation, at least in silence 6 . Such a thing is impossible after the liturgical Constitution.

The final provisions of paragraph 3 of the Constitution were preceded and prepared by a study of scholars of exegesis and historians of Catholic dogmas and theology, such as M. Meinerz, K. Lübeck, P. Browe, H. Weisweiler, A. Chavasse, G. Davanze ${ }^{7}$. On the basis of their work, even before the adoption of the liturgical Constitution, it was obvious and scientifically certain that the intensification of the sacramental anointing of the sick to cases of hopelessness and to the last moments of their lives was not sufficiently justified in the Scriptures or in the tradition of the ancient and early medieval Church, whose laws required only a serious illness to receive this sacrament, and not a hopeless one. Also, the letter of St. Jacob 5:14, added the biblical scholars, does not speak of the hopelessly sick, but only of the bedridden or seriously ill. Until the adoption of the liturgical Constitution, Dogmatics, who were involved in theological speculation, might not have known the above-mentioned statements of biblical and dogma history and therefore could, in good faith, repeat without any change the theses of their great masters of the Scholastic period. Now that the liturgical Constitution has been adopted, the situation has fundamentally changed: the Council has rejected one of the important theorems of scholastic theories as simply erroneous, forcing far-reaching changes in these theories. Since the Council's decisions are well known, only these theologians will from now on repeat without major changes

\footnotetext{
6 "Non esse hanc unctionem nisi infirmis adhibendam nec illis quidem omnibus, ut Ecclesiae traditio nos docet, sed illis dumtaxat qui tam periculose decumbunt, ut in exitu vitae constituti videantur."

$7 \quad$ M. Meinertz, Theologie des Neuen Testamentes, Bonn 1950. K. Lübeck, Die heilige Ölung in der orthodoxen griechischen Kirche, Theologie und Glaube 1916, 318341. P. Browe, Die letzte Ölung in der abencffändischer Kirche des Mittelalters, "Zeitschrift für katholische Theologie" 1931, 515-561. H. Weisweiler, Das Sakrament der letzten Ölung in den systematischen Werkender ersten Frühscholastik. "Scholastik" 1932, 331-353; 554-560. A. Chavasse, Etude sur l'onction des infirmes dans l'Eglise latine du ffle au Xie siècle, Lyon 1942. G. Davanzo, L'unzione sacra degli infermi, Torino 1958.
} 
the teachings of the scholastic masters of the fifth sacrament, who will not take the trouble to consider the necessary consequences of the doctrinal decisions of paragraph 3 of the liturgical Constitution.

In order to reveal the necessary consequences of the provisions of paragraph 3, deductive reasoning must be used, since its most important feature is precisely the fact that the reasoning behind the conclusion is necessarily based on the accepted premises. One of the best known forms of deductive reasoning is conditional syllogism, which can be applied in two different ways: modus ponendo ponens consists in the fact that from the truthfulness of the predecessor we conclude that the successor is true; modus tollendo tollens lies in the fact that from the falsity of the successor we conclude that the predecessor is false, i.e. that the assumption is false. In the syllogism "If it rains, the earth is wet," the predecessor is "it rains" and the successor is "the earth is wet." If it is true that it is raining, it is necessarily true that the earth is wet; if it is false that the earth is wet, it is false that it is necessarily also false that it is raining. Conditional syllogism allows only these two ways of deductive, i.e. necessary, results. In turn nothing can be deduced from the falsity of a predecessor about a successor, nor from the truth of a successor about a predecessor. So, if it does not rain, the earth can be both dry and wet e.g. because it is sprinkled by humans. The application of both modes of conditional syllogism to the theorems of the scholastic theories of the fifth sacrament will reveal the necessary changes that the liturgical Constitution requires in these theories.

However, in order to be able to apply these rules of conditional reasoning to scholastic theories, it is necessary to break them down in advance into the simplest theorems and to link the noncomplex theorems with the conditional syllogisms to the doctrinal provisions of paragraph 3 of the Constitution and with each other.

All the scholastic theories understand the sacramental anointing of the sick as the last and a direct preparation of the soul for heavenly happiness. The last and a direct preparation takes place, according to them, in two ways: because of the time of giving and because of the nature of the grace of the sacrament.

Taking into account the concept of sacramental anointing as the last temporal preparation of the soul for eternal happiness, we receive conditional syllogism: if the anointing of the temporally sick is the last and a direct preparation of the soul to receive heavenly happiness, it should be given only in the final danger of loss of life, i.e. only to the dying and in hopeless cases. By virtue of the provision of the liturgical Constitution in point 3 , as indicated above, the successor to this conditional syllogism is certainly false: therefore, the predecessor is also false. The following should therefore be put forward: the first 
statement: the anointing of the sick is not the last and a direct preparation of the soul for heavenly happiness, i.e. it is not the sacrament of the dying.

The scholastic concept of "last rites" as the last and a direct preparation of the soul to receive heavenly happiness because of the nature of the grace of the sacrament is expressed in conditional syllogism: if the anointing of the sick on account of nature and grace is the last and a direct preparation of the soul to receive heavenly happiness, it should be given only in the ultimate danger of losing life, that is, only to the dying and in the last moments of life. Since the successor to syllogism is clearly false in the light of paragraph 3 of the Constitution, it must also be false as its predecessor. As a result we get: the second statement: because of the kind of grace granted, the anointing of the sick is not the last and a direct preparation of the soul to receive heavenly happiness. Both assertions must be given full theological certainty, since they necessarily and manifestly follow from a theologically certain conciliar decision.

The same basic scholastic concept of "last rites" is also the basis of the third conditional syllogism: if the anointing of the sick is, because of the nature of grace, the last and a direct preparation of the soul to receive heavenly happiness, it can only be renewed if the ultimate danger of loss of life is repeated. The successor is equivalent to a claim: in one illness one can give only one sacramental anointing, even if the illness is long lasting; unless in a long-lasting illness milder periods are intertwined with violent and very dangerous attacks - for then the sacrament can be repeated every time the illness attacks again. This is the teaching of St. Thomas, which later became a common good of Catholic theology. Unfortunately, the predecessor of conditional syllogism, on which it is based, proved to be false in light of the liturgical Constitution. According to the rules of conditional syllogism the third statement is that the nature of the grace of the Anointing of the Sick does not justify the impossibility of receiving it more than once in the course of one and the same illness.

The Anointing of the Sick has only one proper effect, i.e. grace; it does not cause an indestructible birthmark or an inseparable bond, such as marriage, priesthood, confirmation, baptism. If, therefore, the nature of the grace of the anointing of the sick does not exclude the possibility of repeating this sacrament in one and the same illness, the further conclusion and the fourth statement is that in one and the same danger of death, multiple acceptance of sacramental anointing is valid. The invalidity of the second anointing of the sick could be justified only by a type of sacramental grace; therefore, if grace does not rule out the possibility of repeating it, the repeated administration of the sacrament in the course of one illness is certainly important. This statement instructs us that the provision of canon 940 prohibiting the repetition of this sacrament 
within a single risk of death is exclusively disciplinary; it concerns only the fairness of repetition. The theological conclusion constituting the fourth theorem is additionally confirmed in the history of the sacrament of the Anointing of the Sick, which was repeated in the rituals of the $9^{\text {th }}$ and $12^{\text {th }}$ centuries preserved until our times. The liturgical Constitution makes no provision for the repetition of the anointing of the sick. However, since the fundamental possibility of repeating this sacrament in one illness is beyond doubt, the Church must be expected to lift the prohibition on repeating the sacramental anointing of the sick, especially in long-term illnesses.

Although the formulation of St. Thomas is the most logical of all the scholastic theories of the "last" anointing, the doctrinal provisions of paragraph 3 of the Constitution force us to abandon his most important theorems. Aquinas reasoned: if the anointing of the sick is, because of the kind of grace given, the last and a direct preparation of the soul to receive heavenly happiness, then the grace of this sacrament is the spiritual healing so perfect, gratia perfectae sanationis spiritualis, that those who die immediately after receiving this sacrament go straight to heaven. Unfortunately, according to the second claim, the predecessor of Thomas' conditional syllogism turned out to be false. Therefore the fifth statement states that the nature of the grace of the sacrament of the Anointing of the Sick does not justify the statement of St. Thomas. which says that the proper result of this sacrament is perfect spiritual healing, gratia perfectae sanationis spiritualis.

The two scholastic theories, Thomistic and Franciscan, together assume, as a starting point for their reasoning, that the anointing of the sick is, for the sake of their own specific grace, the last direct preparation of the soul for heavenly happiness, that is, it removes the last obstacles that may delay happiness; those that have not yet been exterminated by the grace of the sacraments previously received. They differ in their answer to the question of what these obstacles are, which have not been removed by the grace of the sacraments previously received by the sick person. The Franciscan school claims that they are common sins; according to St. Thomas, they are not sins, but remains of sins, reliquiae peccatorum. A setailed definition of the relevant effect of the fifth sacrament was carried out in both theories based on the following conclusion: if the fifth sacrament is, because of the nature of grace, the last and a direct preparation of the soul for heavenly happiness, its proper result is either the forgiveness of light sins, according to the Franciscan school, or the removal of the remains of sins, reliquiae peccatorum. This conditional syllogism also has no evidential value because its predecessor is false. So, one should state the following sixth statement: by the nature of the grace of the fifth sacrament, neither the Thomistic 
assertion that its proper effect is to remove the remains of sins, nor the Franciscan assertion that its proper effect is the forgiveness of light sins, follows from the nature of the grace of the fifth sacrament.

The last two claims, the fifth and the sixth, should be understood strictly: they do not prove the falsity of the Franciscan and Thomistic theses, but only show that the aforementioned theses were deprived of their justification by the liturgical Constitution; they were hanging in a vacuum. Anyone who still wants to maintain it now, after the liturgical Constitution, is forced to find a new justification for it in the sources of revelation.

The concept of direct preparation for blue happiness is inextricably linked with the concept of indirect preparation. According to both scholastic theories, it indirectly prepares the soul for heavenly happiness by sanctifying grace, acquired in justification and increased either by personal merit or by receiving other sacraments. There is a necessary link between the two preparations, which stems from the nature of each: direct preparation is impossible if indirect preparation has not yet been completed, i.e. direct preparation always indicates and with the necessity that indirect preparation has also been carried out. The relationship between the two preparations, direct and indirect, provided the two theological schools of the Middle Ages with a basis for the following deductive conclusion: if the sacrament of the Anointing of the Sick is, due to the nature of the grace given, a direct preparation of the soul for heavenly happiness, it presupposes an indirect preparation of the soul through the possession of sanctifying grace, that is, the sacrament of the living. This conditional syllogism was the proper basis for including the fifth sacrament in the group of living sacraments. Unfortunately, the predecessor of this syllogism turned out to be false in light of the liturgical Constitution, and therefore the following seventh statement should be made: the nature of the grace of the sacrament of the Anointing of the Sick does not justify its inclusion in the category of living sacraments.

Although the Anointing of the Sick has become a common practice among theologians, it has not become a Catholic doctrine because the Church wants to go beyond the theological schools and has therefore taught the effects of the sacrament in such a general way that it can be considered a living sacrament as well as a dead one. This sacrament, says the Council of Trent (D 927), gives grace, forgiveness of sins, relief to the sick. This deliberate general definition of the effects of this sacrament is undoubtedly closer to what the Scriptures and dogmatic tradition have told us about it.

The inclusion of the fifth sacrament in the group of living sacraments led to artificial complications in learning about its effects. For if it is truly the 
sacrament of the living, only sacramental penance forgives mortal sins committed directly and directly after baptism by Christ's ordination; the anointing of the sick can be forgiven only by side and indirectly, concomitanter et ex consequenti, only if the sick person is incapable of confessing sins or does not remember them at all. If, however, one regains one's memory and strength needed for confession, one is obliged to submit to the ecclesiastical authority to bind and dissolve those sins that have already been forgiven by the sacramental anointing.

Now, after the liturgical Constitution of the Council, this conviction can no longer be upheld, since the inclusion of the anointing of the sick in the living sacraments leads, in the light of the liturgical Constitution, to a denial of the general principle on which Sacramentology bases the division into the living and the dead. The assignment to one of these two groups is determined by the nature of the grace conferred by the sacrament, and the assignment to them is based on the following conditional syllogism: if the nature of the grace of the received sacrament implies the possession of sanctifying grace in the recipient, it is the sacrament of the living; if the nature of sacramental grace does not require the possession of sanctifying grace in the recipient, it is the sacrament of the dead. The reasoning behind the seventh claim demonstrated that the nature of the grace of the sacrament of the Anointing of the Sick does not require that those receiving receive sanctifying grace. Therefore, accepting the general principle of dividing the sacraments into these two classes, it is necessary to accept the following eighth statement: the anointing of the sick is not a sacrament of the living, but of the dead.

Statement 8 is also supported by a very likely additional justification in the Scriptures.

The results of the sacramental anointing of the sick are described in Jacob 5:15: "the prayer of faith will save the sick and raise him up, and if he is in sin, they will be forgiven him." In the New Testament, the word "sin," used without any precise term, means, first of all, mortal sin, grave sin, or a complete sin of the kind. Speaking, for example, of the consequences of sin in general, he points to the consequences of mortal sins: sin deprives sanctifying grace - "For all have sinned and will be cast out of the glory of God" (Rom 3:23); but it is known that the glory of sanctifying grace is deprived of man only by mortal sin. Similarly, St. James, the author of the inspired Catholic letter, points to mortal sin, when James 1:15 presents the genesis and the effect of the sin: "Desire, when it conceives, gives birth to sin, and accomplished sin gives birth to death." Spiritual and physical death is only a consequence of a grave sin. Therefore, the context of the further epistle indicates that "being in sins" is to be understood primarily as mortal sins. In the immediate context of Jacob 5:15 there is nothing to suggest 
that the phrase "if one were in sins" is to be understood only as light sins: that is, all the indications are that the forgiveness of mortal sins is, according to Jacob 5:15, the proper and direct consequence of the fifth sacrament.

The dogmatic tradition does not provide any definite proof for any of the two claims of the shaken alternative. After all, tradition, as the source of the revealed doctrine, identifies itself with the doctrine of the Church, and there is no document of the ecclesiastical teaching office that would explicitly include the fifth sacrament in one of the two classes of the sacraments: the living or the dead. On the other hand, distant, probable foundations are provided by tradition for both theorems. Supporters of the classification of living sacraments may refer to the decree of Pope Innocent I prohibiting the oil anointing of sick penitents because it is a kind of sacrament and penitents are not allowed to participate in the sacraments (D 99); only after public penance and reconciliation with the Church may the sick receive sacramental anointings. The regulation of Innocent I became authoritative for the decline of antiquity. In the early Middle Ages, starting in the $10^{\text {th }}$ century, the anointing of the sick was considered a component of the penance of the sick, which, in view of the unpleasant social consequences of public penance, led to the sacramental anointing of the sick becoming the last rite $^{8}$, even when public penance gave way to a private place.

The anointing of the sick, as a sacrament of the dead, directly and indirectly forgives not only light but also mortal sins, provided that the sick person does not put an obstacle to the forgiveness of sins, that is, he has repentance for sins at least imperfect, attritio. The forgiveness of sins, mortal and light, is just as proper and close to the purpose of the fifth sacrament as the grace to heal the spiritual weaknesses that are the consequence of physical weakness resulting from the illness. From now on, this certain theologically correction should be made permanent to the fifth sacramental treatise.

The doctrine on the effects of the Anointing of the Sick is therefore presented in the following way after the liturgical Constitution: sacraments make what they mean. The visible sign of the fifth sacrament is the anointing with oil, a healing procedure not only for folk but also for scientific medicine. Therefore, the effect of the sacrament is to heal sometimes physically, sometimes from the illness of the body, and always from the spiritual illness of the soul; provided, of course, that the recipient of the sacrament does not obstruct it. Forward sins are a disease of the soul, light as well as mortal sins. The concept of sin as an illness is found in St. John, who divides sins, even mortal sins, into "sins 
unto death," i.e. against the Holy Spirit, and sins not unto death'. Spiritual illness is also a spiritual weakness based on the weakness of the body. The existence of this weakness and the necessity of God's grace to overcome it are indicated by the words of Christ spoken to the disciples in the garden: "Watch and pray that you will not enter into temptation. The Spirit is willing, but the body is faint" (Mk 14:38f). If possessing a body, even a healthy one, is already the source of spiritual impotence and danger, to overcome which the necessary help of grace is necessary, the source of a particular spiritual impotence and particular dangers for the spiritual life is also a serious illness of the body. It is the grace of the Anointing of the Sick sacrament, that is the grace of healing the spiritual impotence associated with the physical impotence of a seriously ill body, which overcomes this particular impotence and the dangers it entails. For the degree of grace that an adult morally receives through the sacrament depends upon the perfection of the disposition with which the sacrament is received, the forgiveness of sins and the removal of spiritual impotence in the sacrament of the anointing of the sick becomes more complete the more zealous the sick person receives the sacrament.

If the anointing of the sick is a sacrament of the living, then only the sacrament of penance is used for the forgiveness of sins committed after baptism. But from the establishment of the same Christ, confession is necessary for the forgiveness of sins in the sacrament of Penance, and the obligation and object of confession is defined in canon 901 of the Code of Law as follows: "Whoever after baptism has committed mortal sins which have not yet been forgiven directly by the keys of the Church, should confess in confession all those whom he is aware of after a careful examination of conscience, and should reveal the circumstances which have changed the species of sin." The quoted canon leaves no doubt: despite obtaining the forgiveness of mortal sins in the sacrament of the anointing of the sick, there is still a serious obligation to present the keys to their ecclesiastical authority in sacramental confession. Only the nature of this obligation remains to be clarified: does the duty to confess mortal sins forgiven in the sacrament of the anointing of the sick come from God's law or only from the Church's law?

The answer to this question depends on whether the anointing of the sick is a sacrament of the living or of the dead; for just as the natural moral law is based on human nature, God's law for sacraments is based on the nature

9 Cf. M. Meinertz, Theologie des Neuen Testamentes, Bonn 1950, Band II, 305; R. Schnackenburg, Die Johannesbriefe, Freiburg and. Br. 1953, 247ff. 
of the sacraments, that is, first and foremost, on the nature of sacramental grace. It is the nature of the grace of the anointing of the sick that it is the sacrament of the dead, that is to say, the sacrament instituted by Christ for the direct and immediate forgiveness of sins for those who need forgiveness. But confession by Christ's ordination is not part of the sacrament of the Anointing of the Sick, that is, neither timely nor intentional, in voto, confession of sins is necessary to obtain their forgiveness in the sacramental Anointing of the Sick. In other words, no need to confess sins is the power of Christ's ordinance - related to the act of forgiveness through the fifth sacrament. So the ninth thesis is that the commandment to confess mortal sins forgiven by the anointing of the sick in sacramental confession does not come from God's law, but from ecclesiastical law.

The Church's issuing of this commandment is explained by the social importance of every human activity: just as morally good life contributes to the growth of social welfare, so bad life - through material and moral harm, through mischief - causes harm to society. The Church, as a community, has a duty to ensure that threats to the social welfare are removed. This duty is fulfilled in such a way that, in the sacramental act of confession, it judges even those evil deeds which have already been forgiven by the sacramental anointing of the sick. The commandment is also explained by the Church's concern for the salvific good of the sinner: for this reason, the Church wants to have insight into mortal sins already forgiven, in order to straighten its conscience.

If such a duty exists, it is understandable that the Church wants the sick person to fulfil it at the same time as receiving the sacramental anointing, if the Church is capable of receiving sacramental confession. For this reason, it normally provides for the combined administration of the two sacraments to the sick: penance and anointing; although it does allow the administration of the anointing itself to those who are unable to go to confession.

In the previous ritual of giving three sacraments together, the following order was in force: confession; wind; last anointing. Point 74 of the liturgical Constitution introduces in its place the following order: confession; anointing; viaticum. The shifting of sacramental communion as a so-called shelter finally has its theological justification in the fact that the sacrament of the Eucharist is a normal means of securing our perseverance in goodness by Christ's ordination, and we must therefore receive it at all times when the grace of perseverance in goodness is particularly necessary for us. Since the entire post-mortem eternity depends on the survival of the last moments of life, we must strengthen ourselves by the grace of the Eucharist for their happy and godly experience. Due to the nature of its grace, the Eucharist is the means by which the soul is prepared to live out the last moments of its life in a godly way. The anointing 
of the sick, as has already been proven, is not, because of the nature of its grace, nor is it the last means of preparing the soul to receive heavenly happiness, nor is it a means of preparing it directly and indirectly for the salutary experience of the last moments of life - for this is the task of the Eucharist: for this reason, it is right that it should be given before the viaticum.

The order in which the "penance - anointing - viaticum," ordered for the future by the liturgical Constitution, is not a novelty, but a restoration of the three sacraments given to the sick, which were prevalent in the early middle ages until the $12^{\text {th }}$ century. In addition to the theological justification, it therefore also has a historical basis.

In the scholastic understanding of the fifth sacrament as a means of directly preparing the soul for heavenly happiness, the following deductive result occurred: If the anointing of the sick, because of the nature of its grace, is a means of directly preparing the soul for heavenly happiness, it can be given only as many times as there is a final danger of losing one's life. In other words, the Fifth Sacrament cannot be validly renewed unless, after recovery, the disease resumes and there is a very serious threat of loss of life. This necessary conclusion of the scholastic understanding of the fifth sacrament has been softened - and in accordance with the tradition of ecclesiastical legislation on this sacrament - by the provision of canon 940, paragraph 2, which is still in force: "This sacrament cannot be repeated in the same illness, unless the sick person, after receiving it, becomes adorned and falls into a new danger of losing his life." In light of the third and fourth assertions, this prohibition on renewing the anointing of the sick during one and the same illness is of a purely ecclesiastic origin and can therefore be modified by the Church. It can be expected that the Church will allow the sacramental anointing to be repeated, especially in the case of long-term illnesses.

The change in the definition of the subject and the time of the fifth sacrament, made by the liturgical Constitution for pastoral reasons in particular, concerns the secondary issue of the entire teaching on the anointing of the sick. However, if through the necessary, deductive deduction one could detect as many as 9 theorems inextricably linked with this change; if these are new statements in the theological treatise on the fifth sacrament, if some of them concern the most important issue in the science of the sacraments, namely the nature of the grace of the sacrament of the Anointing of the Sick, then the above considerations are a telling example of how closely the various statements of Catholic theology are interlinked and how effective strict, deductive thinking is as a tool for the development of theology. 